\title{
PEGELOLAAN WEBSITE DAN PRODUKSI KONTEN MULTIMEDIA UNTUK WEBSITE HKBP PERUMNAS TANGERANG
}

\author{
Jumadal Simamora ${ }^{1}$ \\ 1, Universitas Pelita Harapan \\ Jumadal.simamora@uph.edu,
}

\begin{abstract}
Abstrak
Perkembangan teknologi komunikasi, khususnya internet telah membawa pelbagai perubahan dalam masyarakat. Kecendrungan mengirim dan mengakses informasi dalam masyarakat tidak lagi hanya mengandalkan media cetak dan elektronik, namun sudah beralih ke Internet. Oleh karena itu, banyak institusi bisnis dan sosial keagamaan yang telah mengadopsi media internet (website) sebagai media komunikasi. Gereja HKBP Perumnas Tangerang merupakan salah satu gereja yang telah memiliki website sendiri, namun karena keterbatasan keterampilan, mereka jarang meng-update kontennya. Kegiatan PkM ini bertujuan memberikan ketrampilan bagi jemaat, peserta pelatihan agar mampu mengelola dan memproduksi konten website dalam bentuk multimedia. Kegiatan PkM diadakan dalam bentuk workshop yang materinya disesuaikan dengan kebutuhan peserta. Pembicara pertama membawakan topik, "Pentingnya Penguasaan Teknologi dalam era Informasi saat ini". Kemudian Pembicara kedua membawakan topik "Membuat dan Mengelola Website". Pembicara ke tiga dan ke empat membawakan topik "teknik menulis artikel untuk website". Topik terakhir adalah "Produksi Konten Multimedia untuk Website". Peserta dalam PkM ini adalah mereka yang berpotensi untuk mengelola dan memproduksi konten website seperti perwakilan pemuda, penatua dan remaja yang melek teknologi. Kegiatan PkM ini diadakan di Laboratorium Multimedia Jurusan Ilmu Komunikasi, Universitas Pelita Harapan. Luaran dari PkM ini adalah artikel dan video yang di-upload di website gereja HKBP Perumnas Tangerang. Setelah kegiatan PkM, peserta dapat meng-update dan mengisi konten website gereja.
\end{abstract}

Kata Kunci : Internet, Web site, HKBP, Artikel, Multimedia

\section{PENDAHULUAN}

Perkembangan teknologi informasi dan komunikasi merupakan salah satu faktor perubahan sosial yang terjadi dalam masyarakat. Kemajuan teknologi informasi dan komunikasi telah membawa pelbagai perubahan dalam masyarakat. Bagaimana individu berkomunikasi dengan individu lainnya ikut memengaruhi bagaimana masyarakat terbentuk. Seiring dengan hal tersebut, Menurut McLuhan sebagaimana dikutip Morrissan, dkk (2010:29-30) bahwa perkembangan teknologi merupakan faktor kunci dalam evolusi sosial. Menurut McLuhan, teknologi telah menciptakan revolusi di tengah masyarakat karena masyarakat sudah sangat bergantung pada teknologi dan tatanan masyarakat terbentuk berdasarkan kemampuan menggunakan teknologi.

Teknologi Informasi dan Komunikasi 
McLuhan dalam bukunya the Guttenberg Galaxy (1992) memprediksi bahwa dengan perkembangan teknologi komunikasi, dunia akan berubah menjadi desa global atau sekarang yang kita kenal dengan istilah globalisasi. Menurutnya, media mampu menjadikan dunia tidak lebih sebuah desa atau kampung.

Pada kehidupan sosial saat ini, teknologi komunikasi menjadi jendela kita untuk melihat dunia. Teknologi komunikasi paling terbaru, internet, memfasilitasi kita untuk mendapatkan informasi mengenai peristiwa-peristiwa yang tidak kita alami secara langsung. Di era saat ini, dengan bantuan internet kita dapat mengetahui apa saja yang terjadi dan topik apa yang terpopuler yang sedang berkembang dibelahan dunia lain dalam waktu yang bersamaan.

Kemunculan teknologi media baru, internet telah mengubah cara berkomunikasi manusia. Menurut Nasrullah, (2014:1), teknologi pada hakekatnya memberikan kontribusi dalam menciptakan keberagaman media. Proses penyampaian pesan melalui media pun mengalami pergeseran. Jika selama ini media mainstream, (surat kabar, radio dan televisi) merupakan pusat informasi dan informasi itu dipublikasikan dengan satu arah, kini melalui internet, media menjadi lebih interaktif. Khalayak tidak lagi sekedar objek yang diterpa oleh informasi, tetapi mereka telah dilibatkan lebih aktif.

Berdasarkan standar kerjanya, Nasrullah (2014: 25) mengklasifikasikan media baru dalam beberapa jenis. Pembagian itu tidak hanya didasarkan hanya pada perangkat lunaknya, tetapi juga berdasarkan perangkat keras yang mendukung komunikasi termediasi komputer serta mempertimbangkan kegunaan dan atau fungsi dari media itu sendiri. Jenis media baru tersebut antara lain: 1). Situs (web site), 2). Email, 3). Forum di internet (bulletin boards), 4). Blog, 5.) Wiki, 6). Aplikasi Pesan, 7). Internet "Brodcasting", 8). Peer to Peer, 10. MUDs. dan 11). Media Sosial.

Situs atau web site adalah sistem pengaksesan informasi dalam internet yang dikenal dengan nama world wide web (www), Umumnya dokumen web ditulis dalam format HTML (HyperText Markup Language). Penggunaan hypertext pada web telah dikembangkan dengan menggunakan hypermedia, sehingga sebuah halaman web tidak hanya memuat teks, melainkan juga (gambar), suara (audio), bahkan video (Munir, 2012:196).

Media baru, internet dan website telah memberikan kemudahan bagi manusia dalam berbagai aspek kehidupan. Melalui internet dan website, pertukaran informasi, pemikiran, produk, jasa, dan lain sebagainya menjadi lebih mudah. Internet menyediakan beberapa fasilitas yang dapat digunakan untuk kebutuhan internal organisasi seperti memberikan informasi dan komunikasi perusahaan melalui web. Oleh karena itu, seiring dengan berjalannya waktu, semakin banyak instansi maupun pribadi yang menggunakan website. Website dapat digunakan untuk berbagai fungsi seperti, profil perusahaan, instansi, pribadi dalam membantu kegiatan masing-masing.

Website dapat dibuat dengan berbagai cara, dimulai dengan cara yang paling mudah sampai dengan yang paling kompleks. Dalam membangun sebuah website setidaknya ada 4 cara, antara lain: 1). Instant (blog), 2). Content Management System (CMS: contoh Joomla), 3). Frame Work dan 4). Web Programming. Jika Web Programming harus memiliki kemampuan menguasai Bahasa pemograman HTML, PHP, MySqL, tidak demikian dengan blog. Blog dapat dibuat menggunakan template dengan cara gratis. Meskipun menggunakan template gratis, blog dapat ditampilkan seperti website professional, dengan membeli domain dan hosting.

Dalam menggunakan fasilitas web, menurut Nasrullah (2014:29) blog dapat dibagi menjadi dua. Pertama, kategori homepages, yaitu pemilik menggunakan nama domain sendiri seperti .com, .net. org. Kedua, dengan menggunakan fasilitas penyedia halaman web-blog gratis, misalnya Wordpress (www.wordpress.com), atau blogspot (www.blogspot.com)

Menurut Sukmono, (2012:251), kehadiran weblog merupakan salah satu fasilitas yang dapat digunakan dalam dunia cyberspace menjadikan publikasi yang sebelumnya hanya didominasi oleh media massa, kini dapat dilakukan oleh siapapun yang memiliki akses internet. Flew (2014:34) mengemukakan blog sebagai user created content (UCC), merupakan salah satu praktik Citizen Journalism yang memungkinkan pengguna dapat

Teknologi Informasi dan Komunikasi

125 
membuat dan mendistribusikan konten digital, seperti artikel, video, gambar dan animasi.

Sebagai sebuah organisasi, pemanfaatan website untuk menyampaikan informasi tampaknya telah disadari oleh HKBP Perumnas Tangerang, sehingga HKBP Perumnas Tangerang telah memiliki website dengan url: http://www.hkbp-perumnastangerang.org/web/. Website yang dibuat pada tahun 2018 menggunakan wordpress namun sudah memiliki domain dan hosting sendiri. Website tersebut berisi konten gambar dan teks berbagai kegiatan gereja seperti kegiatan rutin (jadwal ibadah, event yang akan dan telah dilaksanakan di lingkungan gereja). Website juga berisi profil gereja dan dewan-dewan yang ada di gereja.

Dalam diskusi dengan mitra dan mengobservasi website HKBP, konten web jarang diperbaharui, sehingga informasi yang ada merupakan informasi yang sudah lama. Demikian juga dalam jenis konten, hanya memuat teks dan beberapa gambar. Video yang merupakan salah satu elemen multimedia, tidak ada pada website tersebut. Oleh karena itu, tidak banyak jemaat yang mengakses website tersebut.

Supaya website dikunjungi dan diperhatikan oleh jemaat, maka kontennya harus selalu diperbaharui. Konten video dapat digunakan sebagai media yang dapat menarik perhatian penonton dan dapat menarik warga jemaat untuk mengunjungi laman website tersebut. Sebagaimana dikemukakan Munir (2012:289), karena merupakan elemen multimedia yang bergerak, video merupakan salah satu cara penyaluran informasi yang sangat menarik. Video merupakan sumber atau media yang paling dinamis serta efektif dalam menyampaikan suatu informasi sehingga dapat menarik perhatian pengguna.

Berdasarkan informasi dari mitra, keterbatasan keterampilan mengelola website dan memproduksi konten audiovisual dari pengurus dan jemaat gereja merupakan faktor yang membuat website gereja jarang diperbaharui. Padahal, peluang mengelola sendiri dan memasukkan konten audiovisual ke website HKBP Perumnas Tangerang sangat dimungkinkan. Hal itu dapat dilakukan seiring dengan perkembangan teknologi komunikasi, terutama dengan semakin terjangkaunya harga peralatan elektronik kamera dan video recorder.
Produksi konten multimedia sangat dimungkinkan, terutama ketika saat ini hampir semua orang sudah mempunyai Handphone (HP) smartphone yang memiliki teknologi pengambilan gambar dan video dengan beresolusi tinggi. Hanya saja, kebanyakan orang kurang memaksimalkan manfaat teknologi tersebut untuk tujuan-tujuan positif. Agar maksimal, maka pengguna harus memiliki ketrampilan teknis menggunakannya.

Melihat fakta di atas, sebagai bagian dari Tridarma Perguruan Tinggi, Jurusan Ilmu Komunikasi FISIP, Universitas Pelita Harapan ingin membantu mengatasi permasalahan mitra (gereja HKBP Perumnas Tangerang) dengan mengadakan pelatihan "Pengelolaan Website dan Produksi Konten Multimedia" bagi Jemaat gereja HKBP Perumnas Tangerang.

Pelatihan ini bertujuan agar peserta dapat mengelola dan memperbaharui informasi di website. Selain itu, peserta workshop dapat menulis artikel, berita di lingkungan internal gereja, tidak hanya dalam bentuk teks, gambar, tetapi juga dapat berupa video.

\section{METODE}

Untuk mengatasi masalah mitra, maka PkM dilakukan dalam bentuk workshop. Detail tahapantahapan yang dilaksanakan yaitu:

1. Tahap Persiapan. Melakukan koordinasi dengan pihak gereja. Pada tahap ini, panitia melakukan koordinasi dengan pihak gereja. Gereja akan menentukan siapa saja yang menjadi peserta workshop dan sekaligus menentukan tanggal pelaksanaan. Peserta pelatihan diusulkan tidak lebih dari 30 orang peserta dan disarankan lebih banyak dari pemuda dan remaja dengan pertimbangan mereka lebih melek dengan teknologi.

2. Tahap Persiapan Materi. Materi pelatihan disesuaikan kebutuhan Mitra. Berdasarkan analisis situasi seperti diuraikan dalam pendahuluan, maka akan diberikan beberapa topik dalam pelatihan ini, antara lain:

a) Pentingnya penguasaan teknologi di era saat ini. Bertujuan agar peserta dapat memahami,

Teknologi Informasi dan Komunikasi 
bahwa dalam era saat ini, perlu ketrampilan dalam penggunaan teknologi.

b) Membuat dan Mengelola Website. Bertujuan untuk membekali peserta membuat dan mengelola website.

c) Penulisan Artikel (1). Topik ini bertujuan untuk membekali peserta agar dapat menulis artikel. Pada sesi ini akan diberikan prinsip dasar penulisan berita atau artikel secara umum.

d) Penulisan Artikel untuk Website (2). Sesi ini bertujuan untuk memberikan pengetatahuan kepada peserta tentang penulisan lebih mendalam dan sekaligus peserta dapat langsung praktek menulis artikel.

e) Produksi Konten Video. Materi ini bertujuan agar peserta memiliki ketrampilan memproduksi video untuk website. Dalam topik ini akan dijelaskan tahapan-tahapan produksi video, mulai dari pra produksi, produksi hingga pasca produksi (editing). Pada sesi ini peserta juga akan diberikan teknik pengambilan gambar Pada pelatihan ini, semua peserta diharapkan membawa laptop dan camera video. Jika tidak memiliki camera video, peserta akan dilatih menggunakan smartphone yang mereka miliki.

3. Tahap Pelaksanaan. Sesuai dengan materi dan waktu yang dibutuhkan, pelaksanaan pelatihan dibagi secara bertahap. Tahapan materi yang diberikan disusun berdasarkan urgensi dari settiap topik. Oleh karena itu, pelatihan tahap pertama dimulai dari materi "membuat dan mengelola website", kemudian dilanjutkan dengan penulisan artikel. Materi "Teknik Produksi Video akan diberikan pada pada tahap II.

Diharapkan setalah mengikuti tahapan-tahapan tersebut, para peserta dapat mengelola dan memproduksi konten-konten kreatif untuk website gereja.

\section{HASIL DAN PEMBAHASAN}

Kegiatan PkM dengan tema "Pegelolaan Website dan Produksi Konten Multimedia untuk Website HKBP Perumnas Tangerang" tahap pertama diselenggarakan pada hari Selasa, 25 Juni 2019.
Peserta berjumlah 29 orang yang terdiri dari beragam latarbelakang pendidikan, umur, dan bidang pelayanan seperti penatua, remaja, pemuda, guru sekolah minggu. Kegiatan PkM ini melibatkan 6 (enam) dosen, yaitu Jumadal Simamora, Marsefio Luhukay, Johanes Herlijanto, Sigit Pamungkas, Emrus Sihombing dan Rosse Hutapea. Selain dosen, PkM ini juga melibatkan lima orang mahasiswa, yaitu, Martha Herdhanny (NIM: 00000020767), Agata Fortuna (00000020476), Hasita Varent (NPM: 00000020207), Virgiony Christabella Setyabudi dan Felicia. Sedianya, PkM ini diadakan di Gereja HKBP Perumnas, namun karena keterbatasan peralatan dan fasilitas, kegiatan ini diadakan di Laboratorium Multimedia, program studi Ilmu Komunikasi, Universitas Pelita Harapan, Tangerang.

Mahasiswa yang terlibat, aktif membantu dalam mempersiapkan kegiatan ini, mulai dari melakukan registrasi ulang peserta, memandu acara sesi demi sesi dan sekaligus membantu dokumentasi. Acara dimulai tepat pukul 10.00 dan dibuka dengan doa oleh Jumadal Simamora dan dilanjutkan dengan kata sambutan ketua program studi program Ilmu Komunikasi, ibu Marsefio Luhukay.

Sesi, pertama dibawakan oleh Johannes Herlijanto tentang "Pentingnya Penguasaan Teknologi di Era Informasi Saat ini”. Pada sesi ini, peserta diberikan pemahaman bahwa sejarah komunikasi umat manusia yang dimulai dengan sangat sederhana dan memiliki banyak keterbatasan. Namun seiring dengan perkembangan teknologi komunikasi, proses komunikasi semakin kompleks dan untuk itu perlu penguasaan teknologi dalam kehidupannya.

Materi kedua disampaikan oleh bapak Sigit Pamungkas tentang "Membuat dan Mengelola Website". Sesi ini memberikan penjelasan kepada peserta tentang konsep website dan membangun website. Dari beberapa pilihan dalam membangun website, antara lain Instant (blog), Content Management System (CMS: contoh Joomla), Frame Work dan Web Programming, metode pembuatan website yang diberikan adalah menggunakan blog (Wordpress). Selain pertimbangan kemampuan peserta dan waktu yang terbatas, pemilihan metode tersebut juga mempertimbangkan bahwa website yang sudah eksis dibuat menggunakan wordpress.

Teknologi Informasi dan Komunikasi

127 
Denga demikian, setelah pelatihan, peserta akan lebih mudah mengelola dan meng-update website gereja.

Pada sesi ini, masing-masing peserta membuat account blog sendiri di wordpress. Setelah memiliki account weblog, aktivitas yang dilakukan adalah melakukan customize sederhana, desain layout web, membuat menu utama dan submenu pada web, memposting artikel, gambar dan video. Meskipun menggunakan applikasi wordpress yang notabene lebih mudah, namun peserta yang terdiri dari berbagai latar belakang umur dan pendidikan yang berbeda-beda membuat tahapan demi tahapan dalam pembuatan web harus dilakukan secara perlahan.

Agar peserta dapat lebih mudah memahami materi dan teknis pembuatan dan pengelolaan website, sebagian dosen dan mahasiswa mendampingi peserta. Pendampingan ini dapat membantu proses pelatihan berjalan lebih baik.

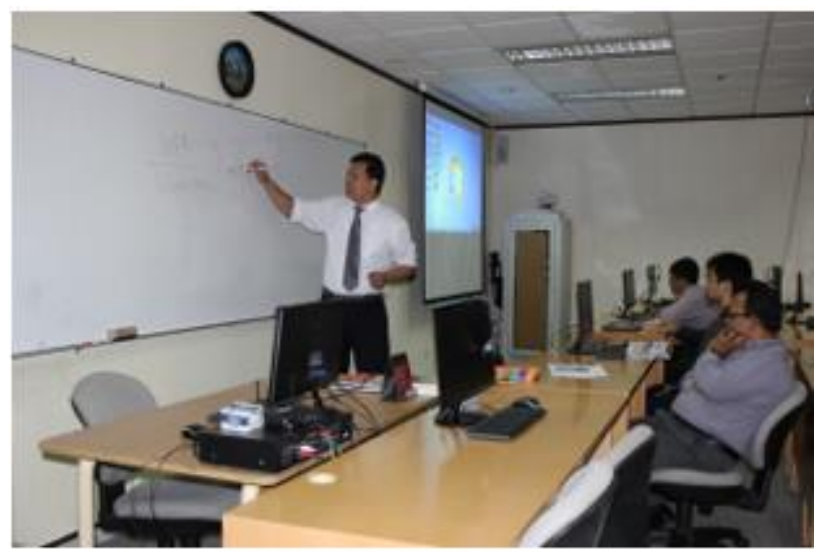

Gambar 1. Peserta sedang memperhatikan materi yang diberikan dosen.

Sesi ketiga adalah "Teknik Penulisan Artikel" yang dibawakan oleh bapak Emrus. Peserta diperkenalkan dengan prinsip-prinsip jurnalistik dan teknik penulisan berita, unsur-unsur penulisan berita, $5 \mathrm{~W}+1 \mathrm{H}$, yakni What (apa), Where (di mana), When (Kapan), Who (Siapa) dan How (Bagaimana), merupakan unsur yang selalu ada dalam berita ataupun artikel.

Selain itu, peserta diberikan pemahaman tentang aspek hukum dan etika dalam penulisan artikel. Dalam penulisan, sebaiknya penulis tidak menyinggung hal-hal yang berbau SARA, menghindari ujaran kebencian. Artikel yang ditulis sebaiknya isu-isu yang teraktual.



Gambar 2. Peserta dari Gereja HKBP Perumnas Tangerang sedang serius mendengar penjelasan dari pemateri

Sesi ke-4 dibawakan oleh ibu Rose Hutapea dengan topik "Penulisan Artikel untuk Media Online. Penulisan artikel pada media online berangkat dari pendekatan penulisan berita. Secara umum, konsep berita pada media cetak, radio, televisi dan online adalah sama. Nilai berita, seperti keluarbiasaan, aktual, kedekatan, proximity, dampak, konflik, ketegangan, tokoh, human interest, kejahatan dan seks adalah nilai-nilai suatu peristiwa yang dapat dijadikan berita. Dikaitkan dengan website gereja HKBP, maka nilai berita, proximity (kedekatan) peristiwa yang terjadi menjadi salah satu pendekatan yang dilakukan dalam penulisan berita atau artikel. Warga jemaat HKBP akan lebih senang membaca berita-berita atau informasi yang terkait dengan mereka, terutama jika mereka menjadi bagian dari pemberitaan tersebut.

Teknik penulisan berita, seperti harus akurat, obyektif dan berimbang juga tetap berlaku pada media online. Akurat berarti sesuai dengan fakta peristiwa. Objektif berarti tidak menambahkan dan mengurangi informasi sesuai dengan pandangan subjektif dari penulis. Sedang berimbang atau balance, tidak memihak kelompok tertentu.

Teknologi Informasi dan Komunikasi 
Gaya penulisan pada media online lebih menerapkan struktur piramida terbalik, yakni memulai penulisan Lead atau paragraph pertama dengan informasi paling penting, sehingga pembaca dapat segera mengetahui intisari informasi yang disampaikan melalui suatu tulisan. Kemudian pada body berita, diikuti dengan penjelasan lebih detail mengenai informasi penting dan diakhiri dengan informasi pendukung, seperti latar belakang peristiwa (Romli, 2012:56).

Meskipun secara umum prinsip penulisan berita dan artikel pada media online dan media cetak sama,yaitu fokus pada teks, namun ada perbedaan diantara keduanya. Teks dan naskah pada media cetak disajikan untuk "dibaca" namun teks pada media online diposting untuk "dipindai oleh pembaca. Oleh karena itu, maka naskah artikel pada media online sebaiknya ringkas dan langsung ke inti berita (to the point).

Tidak hanya membahas teori, pada sesi ini peserta juga diminta langsung praktik menulis untuk artikel. Peserta dibagi secara berkelompok sesuai dengan kriteria pelayanan dan menulis topik yang mereka minati. Topik-topik yang mereka angkat adalah terkait kegiatan dan seputar pelayanan mereka seperti kegiatan pemuda, penatua, sekolah minggu, dan remaja.

Hasil tulisan peserta langsung dievaluasi oleh pembicara. Pembicara memberikan masukan, saran untuk memperbaiki tulisan mereka. Berdasarkan evaluasi dari dosen pemateri, pada sesi ini, panitia memberikan souvenir kepada 3 kelompok peserta yang artikelnya dinilai paling baik.

Meskipun acara mundur hingga jam 16.30 yang sedianya direncanakan selesai jam 15.15, namun peserta antusias mengikuti keseluruhan kegiatan. Diakhir acara, panitia memberikan kesempatan kepada peserta memberikan tanggapan tentang pelaksanaan kegiatan PkM.

Peserta mengaku puas dengan pelaksanaan kegiatan PkM ini. Perwakilan peserta juga memberikan masukan agar diadakan pelatihan lanjutan sekaligus agar mahasiswa ditambah untuk mendampingi mereka ketika melakukan praktek.

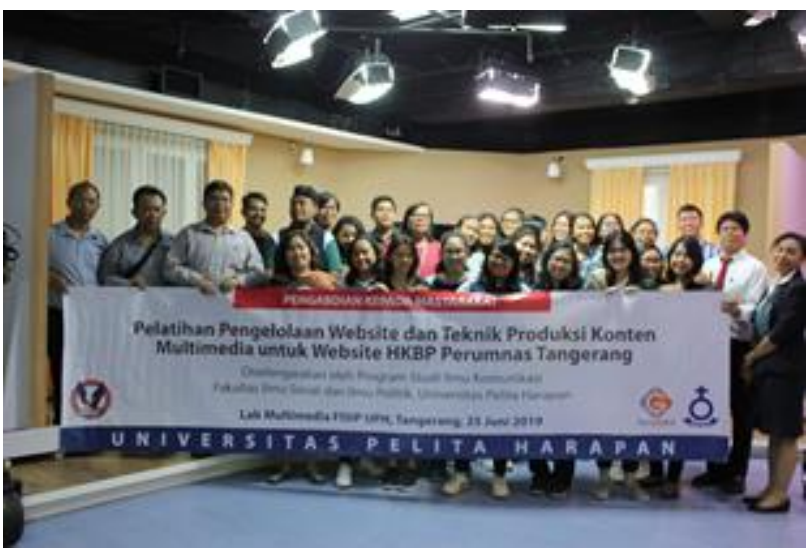

Gambar 3. Pose Bersama Pengajar dan Peserta

Pelatihan di studio TV, Lab Ilmu Komunikasi, $\mathrm{UPH}$.

\section{KESIMPULAN DAN SARAN}

Secara keseluruhan pelaksanaan PkM berjalan dengan baik. Para peserta sangat antusias dalam mengikuti sesi demi sesi dalam keseluruhan acara. Sesuai dengan tujuan PkM, melalui kegiatan ini, peserta telah mampu membuat dan mengelola website gereja HKBP Perumnas. Peserta juga dapat mengembangkan potensi mereka dalam menyediakan dan memproduksi konten-konten artikel yang menarik dan kreatif.

Dengan ketrampilan dan kemampuan yang sudah dimiliki peserta, berbagai kegiatan dan informasi gereja dapat disampaikan melalui website gereja. Warta gereja, artikel laporan peristiwa di lingkungan gereja dapat diposting di website gereja setiap minggu. Warta jemaat yang dibagikan setiap minggu tidak hanya dalam bentuk cetak, namun dalam versi digital. Selain lebih murah dan ramah lingkungan, budaya mengakses informasi melalui internet yang semakin tinggi memberikan peluang bagi website gereja semakin banyak diakses oleh jemaat.

Kerjasama PkM dengan mitra, gereja HKBP Perumnas Tangerang perlu dijalin dan dilakukan secara berkesinambungan. Selain manfaatnya dapat dirasakan oleh mitra, bagi dosen pengajar, kegiatan ini dapat menjadi sarana untuk berkontribusi bagi masyarakat sesuai bidang ilmu atau keahlian masingmasing.

Teknologi Informasi dan Komunikasi 
Sesuai dengan rencana, pelaksanaan tahap berikutnya tentang "Teknik Produksi Video" akan segera diberikan kepada peserta, sekaligus melihat dan mengevaluasi kendala-kendala yang dihadapi mitra setelah mengikuti pelatihan pertama. Jika dirasa perlu, maka mitra akan dibantu supaya semakin lancar dalam pengelolaan dan menulis artikel, terutama produksi konten dalam bentuk multimedia. Selain tema terkait website dan multimedia, pihak kampus dapat memberikan materi-materi lain terkait ilmu komunikasi sesuai kebutuhan mitra, seperti literasi media, public speaking dan topik lainnya.

Meskipun pada sesi penutup diberikan kesempatan bagi peserta menyampaikan tanggapan dan masukan atas penyelenggaraan acara, namun untuk pelaksanaan PkM selanjutnya perlu dibuatkan form evaluasi dalam bentuk kuesioner yang dibagikan kepada peserta, sehingga dapat diketahui data umpan balik peserta mengenai penyelenggaraan PkM secara komprehensif. Data tersebut dapat menjadi bahan evaluasi bagi penyelenggara untuk pelaksanaan PkM berikutnya.

\section{UCAPAN TERIMAKASIH}

Puji Syukur kami panjatkan kepada Tuhan atas terelenggaranya kegiatan $\mathrm{PkM}$ dengan tema Pengelolaan Website dan Produksi Konten Multimedia untuk Website HKBP Perumnas Tangerang. Secara khusus kami mengucapkan terima kasih atas bantuan berbagai pihak sehingga PkM ini bisa terlaksana dengan baik, yaitu:

1. Ketua Program Studi Ilmu Komunikasi, Marsefio Luhukay, S.Sos., M.Si, sekaligus menjadi bagian dari kegiatan PkM ini.

2. Pendeta M. Sidabutar sebagai Pendeta Resort HKBP Perumnas Tangerang, Banten.

3. Penatua St. Shindak Roy Simaremare dan Sekretaris administrasi gereja HKBP, Adelia Silitonga selaku mitra yang telah mengkoordinasi peserta dari jemaat HKBP Perumnas Tangerang.
4. Dr. Ihan Martoyo, Selaku direktur LPPM Universitas Pelita Harapan.

5. Elfi, SE., MM., selaku direktur administrasi Fakultas Ilmu Sosial dan Ilmu Politik Universitas Pelita Harapan.

6. Kepada mahasiswa yang ikut berpartisipasi dalam PkM ini, Martha, Agata, Hasita Varent, Jesscica dan Virgiony Leony.

7. Seluruh rekan dosen yang telah terlibat mengisi materi dalam PkM ini, bapak Sigit Pamungkas, Bapak Johanes Herlijanto, bapak Emrus dan ibu Rosse Hutapea.

8. Staff Laboratorium Ilmu Komunikasi, bapak Giyarno dan Pedrik yang telah mendukung dan membantu PkM ini di lab.

9. Seluruh staff administrasi (Ibu Endah K. Francisca, Rouli, Sri Dewi, Oa, pak Ade) yang telah membantu sehingga PkM ini dapat terselenggara dengan baik.

\section{REFERENSI}

Flew, Terry. (2014) New Media: an introduction. Fourth Edition. Oxford University Press, Australia.

Morissan, Wardhani, Andi Corry, Hamid, Farid. (2010). Teori Komunikasi Massa: Media, Budaya dan Masyarakat. Penerbit, Ghalia Indonesia: Bogor.

Munir. (2012). Multimedia, Konsep dan Aplikasi dalam Pendidikan. Alfabeta, Bandung.

Nasrullah, Rulli. (2015). Media Sosial. Perspektif Komunikasi, Budaya, dan Sosioteknologi. Simbiosa Rekatama Media, Bandung.

Romli, Asep Samsul. (2012). Jurnalistik Online: Panduan Praktis mengelola Media Online. Nuansa Cendikia: Bandung.

Sukmono, Filosa Gita. (2012). Media Baru: Studi Teoritis \& Telaah dari Perspektif Politik dan Sosiokultural. Ruang Publik Alternatif dalam Cyberspace (Geliat Weblog sebagai Online Citizen Journalism) . Hal 243-256.

Teknologi Informasi dan Komunikasi 
Prosiding PKM-CSR, Vol. 2 (2019)

e-ISSN : 2655-3570 